\title{
Population dynamics and habitat partitioning by size, sex, and molt stage of blue crabs Callinectes sapidus in a subestuary of central Chesapeake Bay
}

\author{
Anson H. Hines, Romuald N. Lipcius* \& A. Mark Haddon \\ Smithsonian Environmental Research Center, PO Box 28, Edgewater, Maryland 21037, USA
}

\begin{abstract}
Abundances, size-frequency distributions, sexual composition and molt-stage composition of blue crabs Callinectes sapidus were measured during 1983 to 1985 in the Rhode River, a subestuary of central Chesapeake Bay, USA. Crabs at the mouth and head of the river basin were sampled with monthly triplicate otter trawls. Crabs in the principal tidal creek of the river were sampled $3 \mathrm{~d}$ a week with a fish weir, which caught crabs moving upstream and downstream separately. Crabs exhibited consistent, marked seasonal cycles in abundance as well as considerable annual variation in July peak abundances. New recruits entered the subestuary in late fall and spring and grew rapidly to 70 to $100+\mathrm{mm}$ in their first summer; by the second year they reached mature sizes of 120 to $170 \mathrm{~mm}$. Sixty \% of crabs in the river basin were males; and after maturation and copulation in late summer to early fall, mature females left the subestuary. Crabs partitioned habitats within the Rhode River subestuary by size, sex, and molt stage. Polymodal size structures were similar throughout the river basin, but increased percentages of males were found at the head of the river. Predominantly $(90 \%)$ medium-sized ( 80 to $120 \mathrm{~mm}$ ) males utilized the tidal creek as a molting habitat. Most crabs moving upstream were in premolt, whereas most crabs moving downstream were significantly larger and in postmolt, so that about $70 \%$ of crabs in the creek were near ecdysis. Males and females exhibited significantly lower, but still appreciable (about $2.5 \%$ ) molting activity throughout the river basin. These data provide one of the best documented cases of habitat partitioning by size, sex and molt stage in crustaceans.
\end{abstract}

\section{INTRODUCTION}

The blue crab Callinectes sapidus is widely distributed in the western Atlantic from Cape Cod to Brazil (Williams 1974) and provides an important sport and commercial fishery throughout the southeastern and gulf coasts of North America (Millikin \& Williams 1984). In addition, the blue crab is a key benthic predator controlling abundance, diversity, and structure of various benthic communities (Galtsoff 1964, Virnstein 1977, 1979, Krantz \& Chamberlin 1978, Heck \& Orth 1980, Holland et al. 1980, Blundon \& Kennedy 1982a, b, Laughlin 1982, Arnold 1984, Lipcius \& Hines 1986). Seasonal and migratory activities of blue crabs in Chesapeake Bay are well known (Cargo 1958, Van Engle 1958, Tagatz 1968, Millikin \& Williams 1984), as

\footnotetext{
- Present address: Virginia Institute of Marine Science School of Marine Science, The College of William and Mary, Gloucester Point, Virginia 23062, USA
}

is larval behavior following hatching near the mouth of Chesapeake and Delaware Bays (Sulkin et al. 1980, Epifanio et al. 1984). Mature females hatch their eggs in high salinities at the mouth of the bay in early summer and fall, and planktonic larval development occurs in the neuston on the continental shelf. Newly settled crabs move back into the bay, dispersing throughout the estuary to feed and grow. Mature crabs copulate in late summer and inseminated females migrate $200 \mathrm{~km}$ or more in fall to high salinities at the mouth of the bay to incubate their eggs. Juveniles and mature males bury in mud to overwinter throughout the estuary. Blue crabs live 2 to 3 yr. Although these sexual differences in movement across estuarine habitats during the life history of blue crabs are well known, little is known about their short-term movement and habitat utilization within estuaries.

Some other decapods also move into particular habitats for mating and reproduction (Herrnkind 1983), e.g. deep- to shallow-water migrations by Homarus 
americanus (Cooper \& Uzmann 1980) and Chionoecetes opilio (Taylor et al. 1985, Hooper 1986). However, there is little documentation of habitat selection for molting. Decapods are known to be vulnerable to predation and cannibalism during molting (Reaka 1976, Botsford \& Wickham 1978, Laughlin 1982), and it is generally assumed that they seek spatial and temporal refugia during ecdysis until they regain motility, their carapace hardens, and they can defend themselves adequately (Lipcius \& Herrnkind 1982). Juvenile blue crabs move into estuaries like Chesapeake Bay to feed and grow to maturity during warm summer months and use submerged aquatic vegetation as nurseries in high salinity zones (Heck \& Thoman 1984). However, little is known about habitats used for molting, especially in the middle to upper zones of estuaries such as Chesapeake Bay, where submerged aquatic vegetation has become sparse (Orth \& Moore 1983). This paper analyzes the population dynamics of blue crabs in a tributary of central Chesapeake Bay and shows that large numbers of medium-sized males use a salt creek as a primary molting habitat, whereas most females remain in the main basin of the subestuary.

\section{STUDY SITE AND METHODS}

The Rhode River, Maryland ( $38^{\circ} 51^{\prime} \mathrm{N}, 76^{\circ} 32^{\prime} \mathrm{W}$ ), is in the lower mesohaline zone of the western shore of Chesapeake Bay (Fig. 1). The river is a shallow (max-

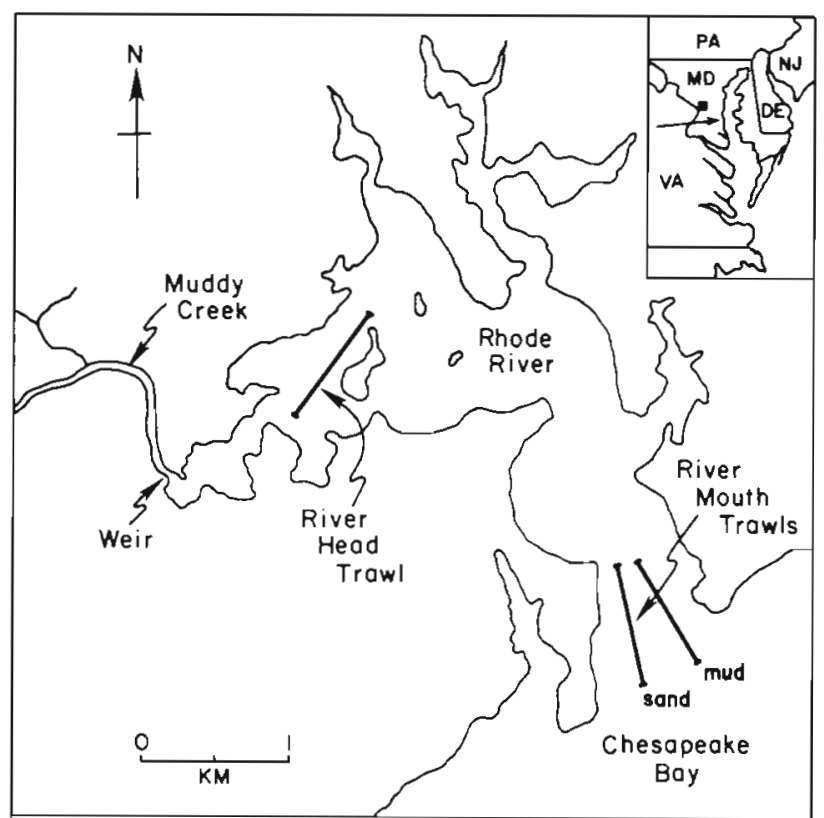

Fig. 1. Map of the Rhode River subestuary, showing the locations of otter trawl stations, Muddy Creek and the weir. Inset shows location of Rhode River on Chesapeake Bay imum depth $=4 \mathrm{~m}$ ), small (485 ha) subestuary with salinities fluctuating seasonally between 4 to $5 \%$ in spring and 12 to $15 \%$ in fall. Water temperatures also cycle seasonally between $0^{\circ} \mathrm{C}$ in January and 28 to $29^{\circ} \mathrm{C}$ in July. Sediments are mostly fine, silty mud with some sandy areas near shore. There was no submerged aquatic vegetation in the subestuary and tidal creeks of the system during the study period.

Muddy Creek is the principal freshwater tributary of the subestuary (Fig. 1). The creek averages $1.5 \mathrm{~m}$ deep in its channel and is about $40 \mathrm{~m}$ wide at the mouth. The creek is influenced by mixed semidiurnal tides with a vertical range of about $1 \mathrm{~m}$ and is never completely emptied. The creek bottom is fine, silty mud; the shoreline is lined by a cattail Typha angustifolia marsh, which is submerged on $70 \%$ of all high tides. Water temperature in the creek cycled seasonally from $0^{\circ} \mathrm{C}$ in January to $33^{\circ} \mathrm{C}$ in July. Salinity at the mouth of the creek fluctuated trom $0 \%$ in May to $14 \%$ in October; salinities $1 \mathrm{~km}$ upstream were not appreciably different.

Blue crabs were sampled from 1983 through 1985 in 2 ways. First, they were sampled by monthly otter trawls ( $3 \mathrm{~m}$ wide mouth; $5 \mathrm{~cm}$ mesh net body; $7 \mathrm{~mm}$ mesh cod end liner; tickler chain) in the open water portion of the Rhode River (Fig.1) from April to November. Each month, trawls were pulled for $900 \mathrm{~m}$ on 3 consecutive days at 3 stations: 2 at the river mouth (mud and sand bottoms, depths of 4 and $2 \mathrm{~m}$, respectively), and 1 at the head of the river (mud bottom, depth of $2 \mathrm{~m}$ ). All crabs from each catch were counted, and a subsample of 20 to 40 crabs were measured to the nearest $\mathrm{mm}$ from point to point across the width of the carapace, sexed, and female sexual maturity determined by abdominal allometry (Hartnoll 1982). Crabs in the subsamples from August to September 1984 and June to October 1985 were also assessed for molt stage by examining carapace calcification and epidermal retraction and setogenesis of the scaphognathite under a dissecting microscope, following documented staging criteria (Drach 1939, Aiken 1973, Peebles 1977. Van Herp \& Bellon-Humbert 1978, Vigh \& Fingerman 1985). The carapace of each crab was also categorized as (1) shiny and clean, indicating recent molting; (2) dull surface with slight to moderate fouling, indicating intermolt and no recent molting; or (3) dirty, stained white ventral surfaces and moderate to heavy fouling by algal films, indicating the crab had been in intermolt for a long time.

Second, all crabs larger than $2.5 \mathrm{~cm}$ were trapped in a fish weir constructed across the mouth of Muddy Creek (Fig. 1). V-shaped fences funneled crabs and other motile organisms moving upstream or downstream into separate $7 \mathrm{~mm}$ mesh hoop nets. The weir was fished 3 d per week, except when the creek sur- 
face was frozen during January; during the other $4 \mathrm{~d}$, an open gate allowed organisms to pass freely through the weir. All crabs trapped in the weir after $24 \mathrm{~h}$ periods were counted and a subsample of 20 to 40 crabs measured and sexed as described above. Crabs were then released back into the creek on the side of the weir where they were headed. Crabs in the subsamples from August to September 1984 and June to October 1985 were also molt-staged and categorized by carapace condition, as explained above.

\section{RESULTS}

The abundance of blue crabs caught in otter trawls in the main basin of the Rhode River fluctuated seasonally, with peak catches in mid-summer and lows in late fall and early spring (Fig. 2). The seasonal cycle in crab abundance was partitioned from $\log _{10}$-transformed data by ANCOVA with trigonometric functions as covariates (Bliss 1970, Holland 1985, Hines et al. 1986), and the residuals were tested for homogeneity of variance $\left(\chi^{2} ; p>0.1, \mathrm{df}=2\right.$ and 3 , respectively) and of slope (ANCOVA). Abundances differed significantly among years and stations, and there was significant interaction between year and station factors (ANCOVA, $p<0.01$ ). Crabs were much less abundant in 1983 than in 1984 and 1985, and consistently fewer crabs were caught at the river head than at the river mouth (Fig. 2). However, an independent test showed that abundances did not differ between catches in trawls over sand and mud sediments at the river mouth (ANCOVA, $p>0.2$ ). Assuming a catch efficiency of $22 \%$ (based on studies of similar trawl gear in similar Chesapeake Bay habitats; Homer et al. 1980), peak densities in the Rhode River ranged from 0.10 crabs $\mathrm{m}^{-2}$ in 1983 to 0.73 crabs $\mathrm{m}^{-2}$ in 1984 and 1985 .

The sexual composition of the trawl catch was about $60 \%$ males and $40 \%$ females year-round (Fig. 3 ); there were no interannual differences in sexual composition (G-test, $p>0.4$, df $=4$ ). From April through July, juvenile females comprised 25 to $30 \%$ of the catch, but in September to October the percentage declined to about $10 \%$ of the population, concurrent with a sharp increase in the percentage of mature females. However, by November mature females were not caught.

r.ig. 2. Calinectes sapidus. Abundance of blue crabs caught in otter trawls at 3 stations in the Rhode River during 1983 to 1985 . Means are plotted for triplicate trawls at about monthly intervals. See Fig. 1 for station locations. (O) River mouth, sand bottom; (•) river mouth, mud bottom; $(x)$ river head, mud bottom

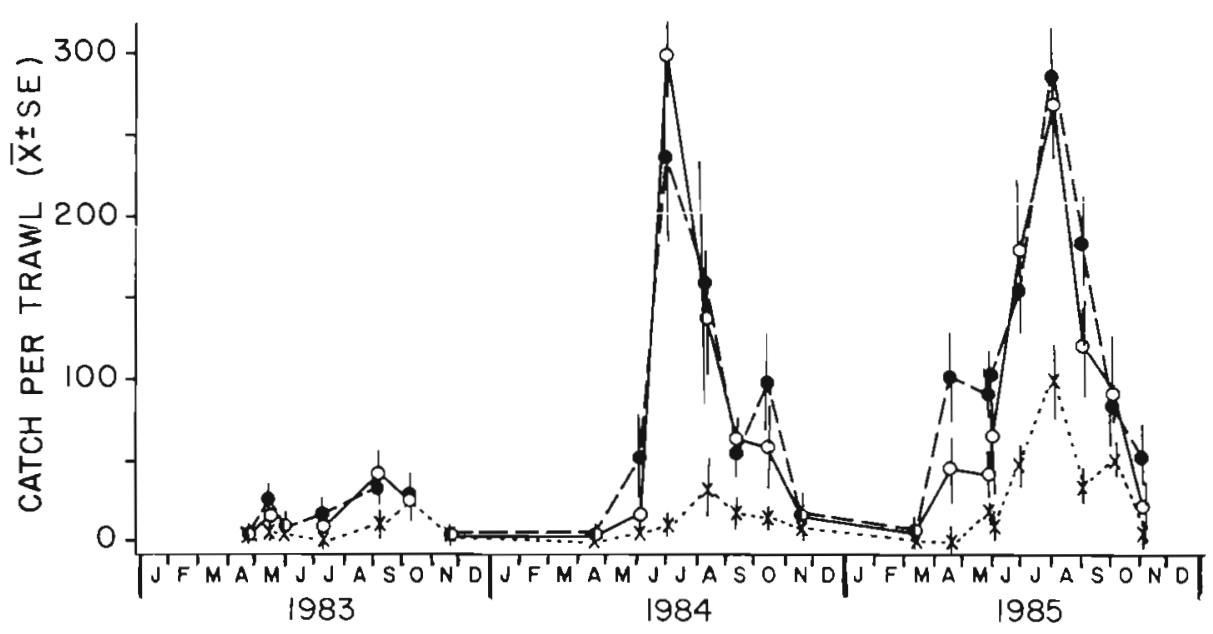

Fig. 3. Callinectes sapidus. Seasonal changes in sexual composition of blue crabs caught in otter trawls in the Rhode River. Plotted means are based on composition of catches averaged for each month over 3 yr (1983 to 1985). For females, $\mathrm{J}=$ juvenile; $\mathrm{M}=$ mature

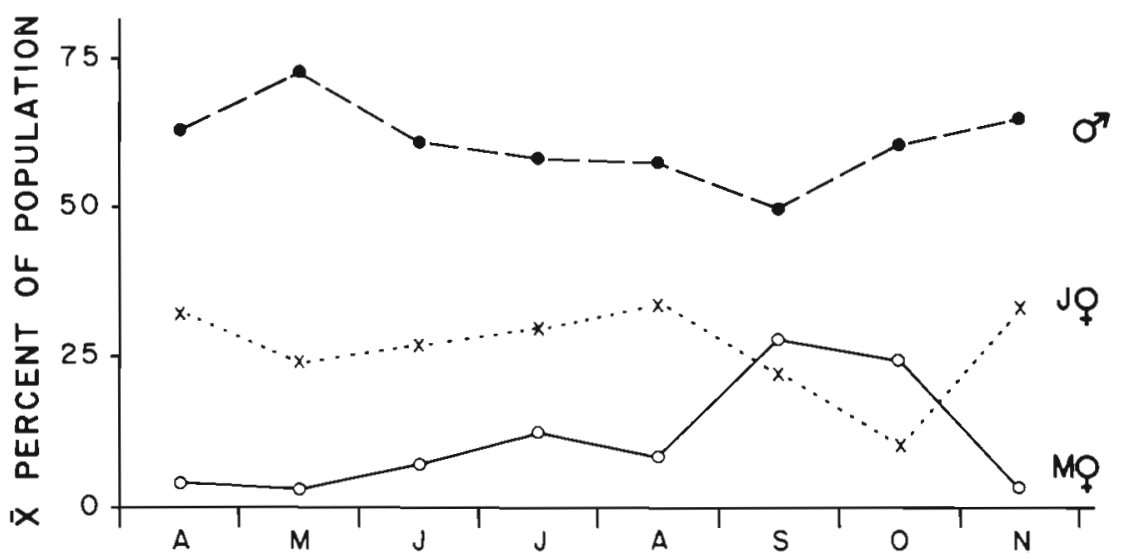


The size structure of the crab population also showed a consistent pattern each year (Fig. 4). Two distinct size-classes, with modes at about 30 and $100 \mathrm{~mm}$ in carapace width for both males and females, were present in early spring when crabs first became active.
Both of these groups grew rapidly, so that by July the modes were about 65 to $75 \mathrm{~mm}$ in both sexes and $135 \mathrm{~mm}$ in males or $155 \mathrm{~mm}$ in females. In females, the larger size-class was comprised of mature individuals. From August to October, the juvenile female mode

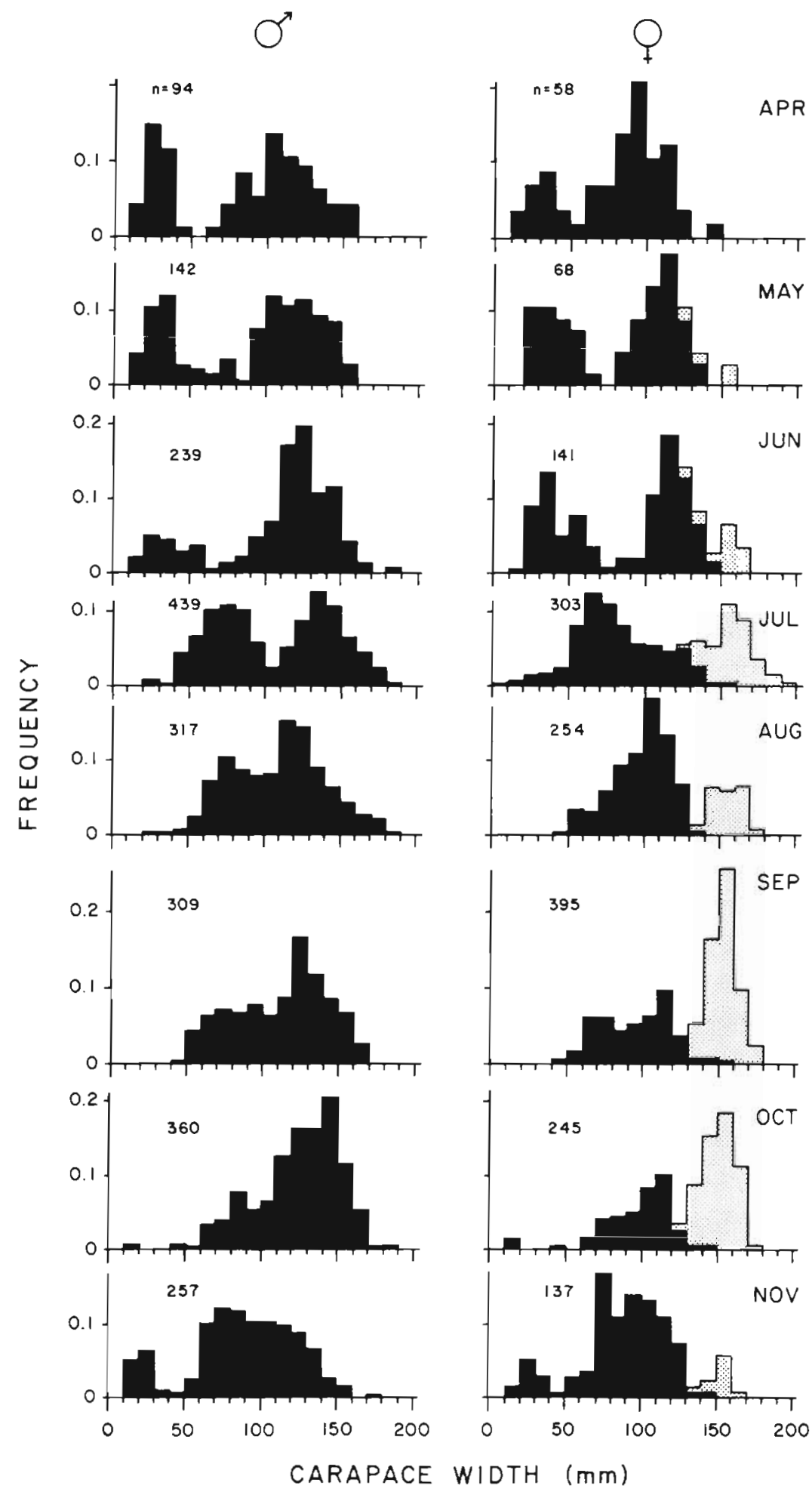

Fig. 4. Callinectes sapidus. Seasonal changes in population size-structure of male and female blue crabs caught in otter trawls in the Rhode River. Each monthly size-frequency distribution is based on crabs caught in that month over 3 yт (1983 to 1985). For females, histograms are additive, with solid $=$ juvenile and stippled $=$ mature crabs. Sample sizes are indicated 
continued to grow to $115 \mathrm{~mm}$ and the percentage of crabs in the larger size-class increased as females matured. Males also showed both continued growth and increased prevalence of large crabs with a mode at $145 \mathrm{~mm}$ in October. In November, most of the crabs larger than $130 \mathrm{~mm}$ disappeared and a new small sizeclass entered the population.

Blue crabs moved into Muddy Creek from May to October, with typical mean fluxes of $125 \mathrm{crabs} \mathrm{d}^{-1}$ and peak catches averaging 60 to $275 \mathrm{crabs} \mathrm{d}^{-1}$ in August in the upstream weir net (Fig. 5). The number caught in the downstream net did not differ significantly from the upstream catch when seasonal cycles in abundance were partitioned with trigonometric functions (ANCOVA, p>0.05; Bliss 1970, Holland 1985, Hines et al. 1986). However, abundances differed significantly among years; like the crabs in the main Rhode River basin, fewer were caught in 1983 than 1984 and 1985.

The size structure of blue crabs sampled over the 3 yr period was similar at the river mouth and river head stations, both for males with 3 distinct modes at about 25,80 , and $130 \mathrm{~mm}$ and for females with 4 modes at about 30, 70, 110, and $150 \mathrm{~mm}$ (Fig. 6). Unlike crabs caught in the river basin, size-frequency distributions of crabs moving upstream and downstream in the creek did not change seasonally (Kolomogorov-Smirnov tests, $p>0.2$ ). However, the size distribution of both males and juvenile females in the creek differed significantly from those in the river basin (Kolomogorov-Siminuv tests, $p<0.01$; Fig. 6). Males in the creek samples had unimodal distributions, with those moving downstream being significantly larger $($ mean $=127 \mathrm{~mm}$, mode $=130 \mathrm{~mm})$ than those moving upstream $($ mean $=107 \mathrm{~mm}$, mode $=110 \mathrm{~mm})($ Kolomo-
gorov-Smirnov test, $p<0.01$ ). Similarly, juvenile females moving downstream were significantly larger (mean $=112 \mathrm{~mm}$, mode $=120 \mathrm{~mm}$ ) than those moving up the creek $($ mean $=89 \mathrm{~mm}$, mode $=100 \mathrm{~mm})($ Kolomogorov-Smirnov test, $p<0.01$ ). Mature female size did not differ significantly among locations (mean = $148 \mathrm{~mm}$, mode $=150 \mathrm{~mm}$; range: 95 to $183 \mathrm{~mm})(\mathrm{Kolo}-$ mogorov-Smirnov tests, $\mathrm{p}>0.3$ ).

Sexual composition differed significantly among locations (G-test, $\mathrm{p}<0.001$, df $=8$ ) (Fig. 7). Although the composition did not differ significantly between mud and sand sediments at the river mouth (G-test, $p>0.05$, $d F=2$ ), the percentage of males increased from about $54 \%$ at the river mouth and $65 \%$ at the river head to $91 \%$ in the creek (G-test, $\mathrm{p}<0.001$, df $=$ $2)$. Conversely, the proportion of mature females declined from about $17 \%$ at the river mouth to only $1 \%$ in the creek (G-test, $\mathrm{p}<0.05$, df $=2$ ). Proportions of juvenile females were similar at both locations in the river basin but significantly lower in the creek (Gtest, $\mathrm{p}<0.01$, df $=2$ ). Sexual composition in the creek did not differ among crabs moving upstream and downstream, nor did it differ among months of the summer season (G-test, $p>0.2$, df $=2$ and 6 , respectively).

Molt stages were grouped into 4 categories: postmolt (Stages A and B), intermolt (Stage C), early premolt (Stage $D_{0}$ ), and advanced premolt (Stages $D_{1}$ to $E$ ). Molt stage composition differed significantly by location and sex $\left(\chi^{2}, \mathrm{p}<0.001\right.$; Fig. 8). A large proportion (14 to $33 \%$ ) of males and juvenile females were in transition to premolt at all locations. Mature females, however, were not observed in premolt. Although the composition of molt stages did not differ significantly between the stations at the river mouth and river head
Fig. 5. Callinectes sapidus. Abundance of blue crabs caught in the upstream and downstream nets of the weir at the mouth of Muddy Creek from 1983 to 1985 . Monthly means of 24 h catches $(N>11)$ are plotted. ( $\bullet$ Upstream catch; (O) downstream catch

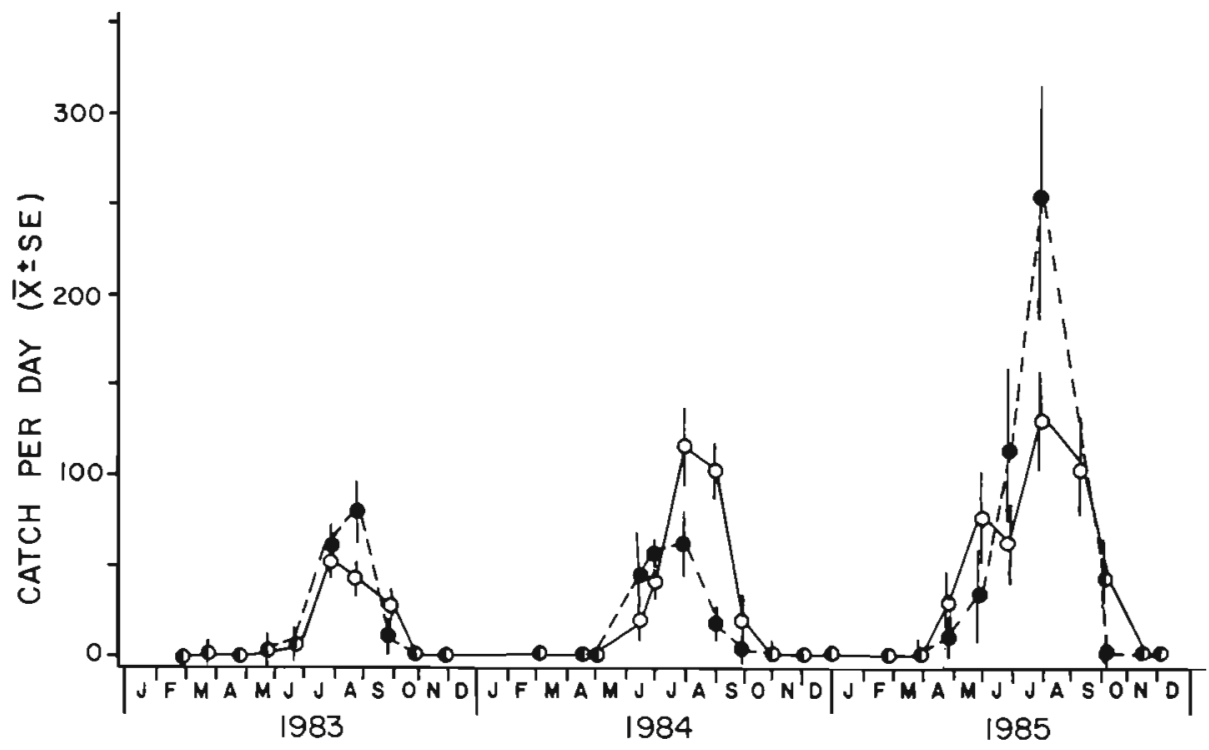

1985 


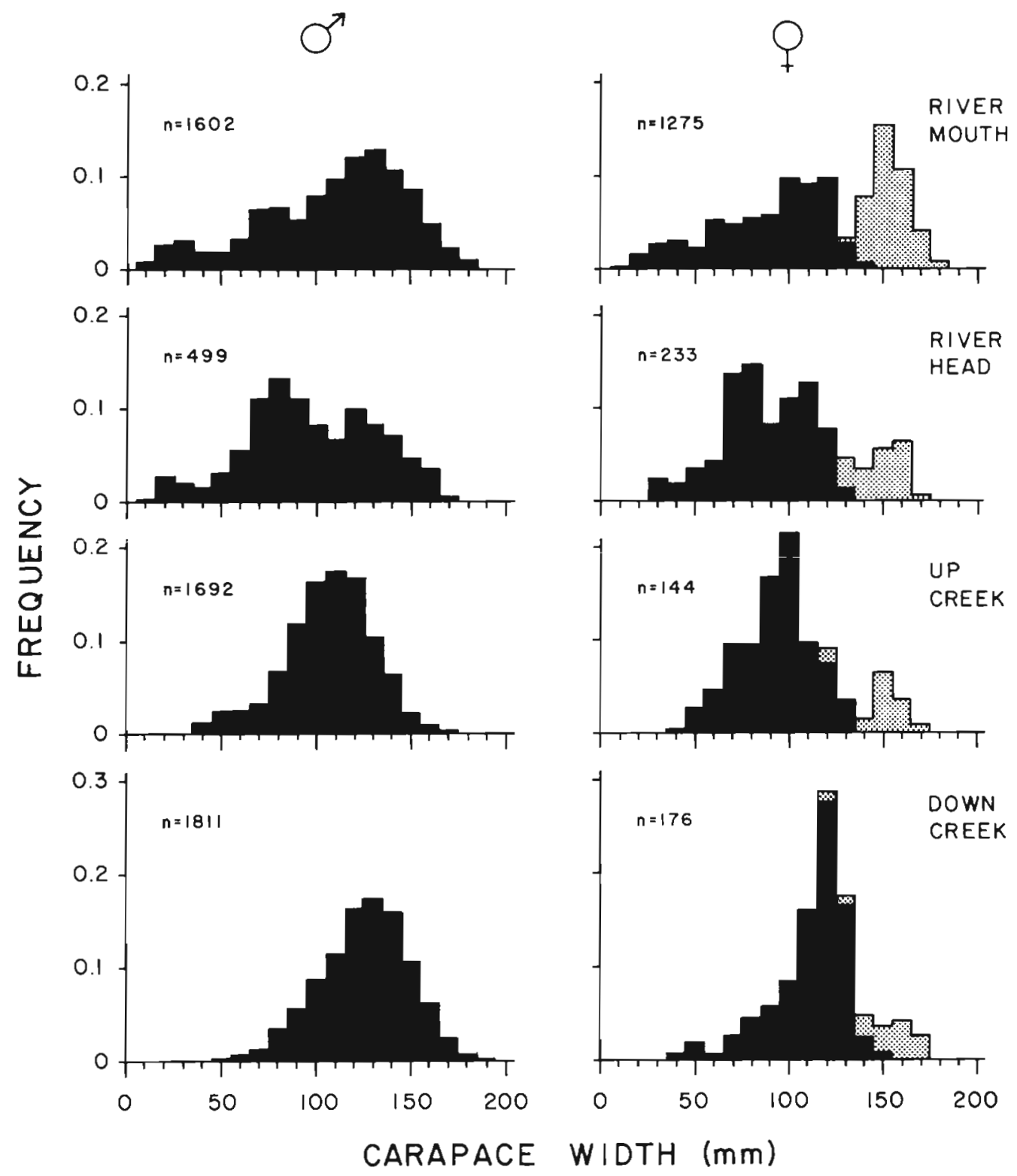

Fig. 6. Callinectes sapidus. Spatial differences in size-frequency distributions of male and female blue crabs in the Rhode RiverMuddy Creek system. Samples were composited for 1983 to 1985 from otter trawls at the river mouth and river head stations, as well as upstream and downstream nets for the weir in Muddy Creek (see Fig. 1). For females, histograms are additive, with solid $=$ juvenile and stippled $=$ mature crabs. Sample sizes are indicated

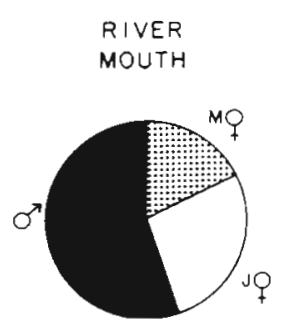

$n=2749$

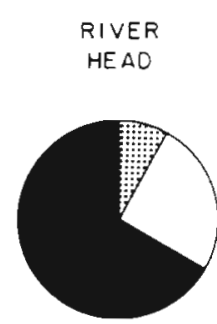

751

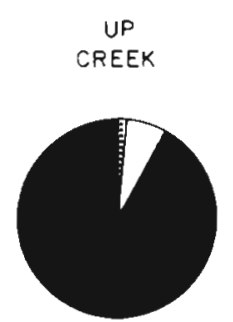

1836

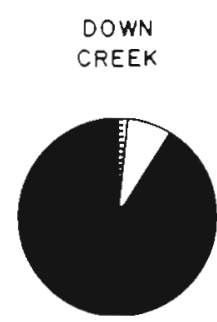

1987

Fig. 7 Callinectes sapidus. Spatial differences in sexual composition of blue crabs in the Rhode River-Muddy Creek system. Samples were composited for 1983 to 1985 from otter trawl catches at the river mouth and river head stations, as well as from upstream and downstream nets for the weir at Muddy Creek (see Fig. 1). Percentages of males, juvenile (J) and mature (M) females at each lacation are indicated as shown for the river mouth pie chart 

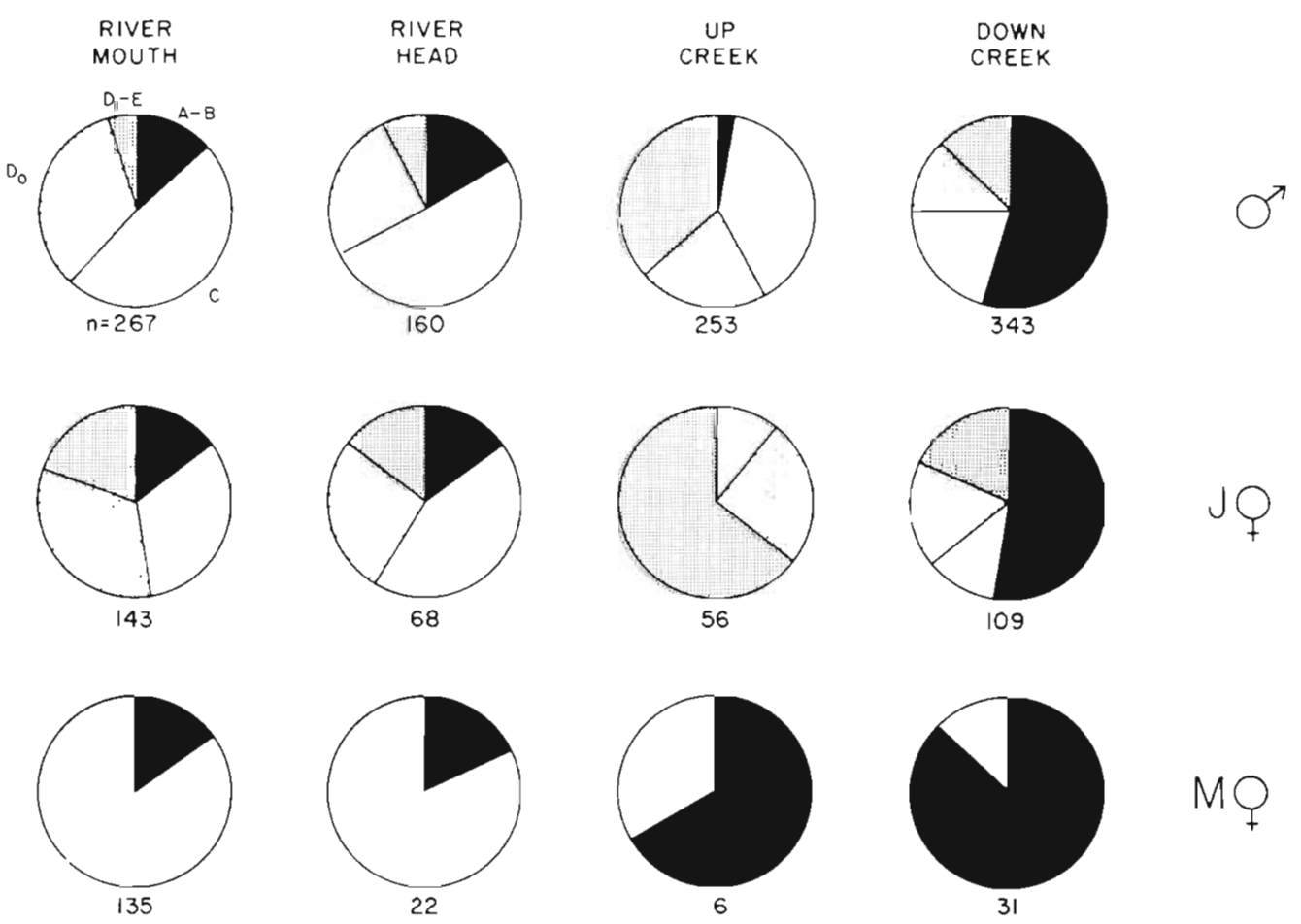

Fig. 8. Callinectes sapidus. Spatial differences in molt stage composition of male, juvenule (J) and mature (M) female blue crabs in the Rhode River-Muddy Creek system. Samples were composited for 1983 to 1985 from otter trawls at the nver mouth and nver head stations, as well as from upstream and downstream nets for the welr at Muddy Creek (see Fig. 1). Percentages of crabs in postmolt (Stages $A$ and B), intermolt (Stage C), transition to molt (Stage $D_{0}$ ), and premolt (Stages $D_{1}$ to E) are indicated as shown tor the river mouth, male pie chart

for any of the 3 categories of sex and maturity (G-tests, $\mathrm{p}>0.1$, di $=3$, moiting activity was much higher in the creek than the river basin for each category (G-test, $p<0.001$, df $=3)$. Large proportions of males $(40 \%)$ and juvenile females (68\%) moving up the creek were in premolt compared to crabs in the river (6 to $21 \%$ ) (Fig. 8). Very few (2\%) of males and no juvenile females going up the creek were postmolt, whereas large proportions (55 and $53 \%$, respectively) of those going downstream were in postmolt (Fig. 8). Most (66 to $82 \%$ ) of mature females in the creek were postmolt, compared to $<20 \%$ in the river basin, although the proportion going down the creek was not significantly higher than going up (G-test, $\mathrm{p}>0.1$, df $=3$; Fig. 8). The numbers, size-frequency distributions, and percentages of premolt and postmolt crabs did not differ significantly among weeks or months of the summer season for either upstream or downstream crabs (ANCOVA, $p>0.1$; Kolomogorov-Smirnov tests, $p>$ 0.1 ; G-tests, $p>0.1$ ). Although molt stages were not assessed quantitatively in 1983 and much of 1984 , qualitative field notes for these years indicate that upstream crabs were also predominantly premolt stages and downstream crabs were predominantly postmolt stages, as judged by the degree of carapace fouling and the presence of soft postmolt crabs. Judg- ing by their clean, unfouled caranaces, nearly all $(78 \%)$ of the intermolt crabs (Stage C) moving downstream through the weir were also recently molted, suggestıng that they had passed through postmolt whlle upstream of the werr.

\section{DISCUSSION}

Blue crabs in the Rhode River subestuary exhibited marked seasonal cycles in abundance as well as considerable annual vanation in peak abundance in trawl (Fig. 2) and weir (Fig. 5) samples. Seasonal shifts in size structure (Fig. 4) indicate that the population was composed of 2 year classes, with new recruits entering the subestuary in late fall and spring and growing rapidly to 70 to $100+\mathrm{mm}$ in carapace width during summer. By the following spnng this year-old cohort grew to the 100 to $150 \mathrm{~mm}$ size range of mature crabs. Most $(60 \%)$ of the crabs in the river basin were males throughout the year; and after maturation and copulatıon in late summer to early fall, mature females left the subestuary (Fig. 3). These essential features of population dynamics are in good agreement with the life history paradigm for the blue crab in Chesapeake Bay, with females migrating in fall to the bay mouth to 
hatch their eggs, juveniles dispersing throughout the estuary to feed and grow in summer, and the life span being about 2 yr (Millikin \& Williams 1984). Large annual fluctuations in abundance are characteristic of blue crab populations, apparently as a result of environmentally induced variations in recruitment (Ulanowicz et al. 1982, Tang 1985).

Movement to particular habitats by decapods has been associated with various selective advantages (Hermkind 1983). The advantage of movement from cryptic to open habitats and cuing behavior by Panulirus argus remains unclear (Hernkind 1983). However, seasonal movement on- and off-shore by Homarus americanus is advantageous for maintaining a thermal optimum from the resulting vertical changes in depth (Cooper \& Uzmann 1980). Migrations of terrestrial crabs (Gecarcinidae, Coenobitidae) are associated with the reproductive requirement of hatching eggs in the ocean, but also apparently result in temporary high densities of crabs that facilitate location of mates (Wolcott \& Wolcott 1985). The fall migration of mature female blue crabs Callinectes spp. to the high salinities at mouths of estuaries may result in improved reproductive success because sensitive eggs and larval stages are: (1) buffered from stressful fluctuations of physical parameters in low salinity zones of the estuary; (2) subjected to reduced predation pressure; and/ or (3) afforded greater dispersal (Norse 1977, Strathmann 1982). Movement of juvenile blue crabs and other species into low salinity areas during warm months provides feeding access to the productive estuaries during the rapid growth phase of the crabs' life histories.

Crabs partitioned habitats within the Rhode River subestuary by size, sex, and molt stage. Polymodal size structures were similar throughout the river basin, but increased percentages of males were found at the head of the river. Predominantly medium-sized males utilized the tidally-influenced portion of its main tributary as a molting habitat. Approximately 9000 crabs, about $90 \%$ of which were 80 to $120 \mathrm{~mm}$ males, moved up into the creek over summer and fall. Most crabs moving upstream were in premolt, whereas most crabs moving downstream were significantly larger postmolt individuals. Although less than $10 \%$ of crabs in the creek were females, most of these were molting. Both males and females were molting at a significantly lower, but still appreciable rate 20 to $30 \%$ in Stages $D_{1}$ to $B$ ) throughout the river basin. However, because most females did not go into the creek, it is not clear whether they were molting throughout the river basin or perhaps moving into another subhabitat, such as the near-shore shallows, which were not sampled by otter trawls. Regardless of sex and size, blue crabs were not utilizing submerged aquatic vegetation as a refuge for molting (Heck \& Thoman 1984), because none was present in the Rhode River subestuary and nearly all such beds have disappeared from upper and central Chesapeake Bay in recent years (Orth \& Moore 1983).

There are at least 3 possible selective advantages to blue crabs using salt creeks as molting habitats. First, there may be an osmotic advantage to molting in reduced salinities, because of the need to take up large quantities of water to expand the exoskeleton immediately after ecdysis. The mechanism for this rapid uptake is unclear in isosmotic, stenohaline crabs (Born 1970), but it is evident in a hyperosmotic, euryhaline animal. However, the precise microhabitat for ecdysis needs to be identified to evaluate this hypothesis, because vertical stratification of salinity in the creek channel results in much of the bottom being exposed to salinities similar to those in the open-water basin of the Rhode River, while salinities along the creek shallows can be significantly lower ( $T$. Jordan, Smithsonian Environmental Research Center, pers. comm.). Moreover, blue crabs readily molt in a wide range of salinities (Millikin \& Williams 1984, pers. obs.).

Second, molting in the creek habitat may minimize mortality due to predation and cannibalism during the vulnerable period surrounding ecdysis. Intermolt blue crabs readily attack soft (molt stages A and B) crabs; whereas late premolt and early postmolt crabs cease feeding, as do other decapods (Hartnoll 1982, Lipcius \& Hermkind 1982). Because nearly all of the crabs in the creek were in these non-feeding stages, and most of the crabs in the open-water basin were in intermolt and actively feeding, molting in the creek reduced the risk of cannibalism. Fish which would eat small, soft blue crabs (e.g. Morone americana) were common in both the open-water basin and the creek (Hines et al. 1986, Hines \& Haddon unpubl.). However, it is not clear whether soft crabs in the modal size range $(100+\mathrm{mm})$ present in the creek were small enough to be susceptible to predation by these medium-sized fish (modal size $=150 \mathrm{~mm}$ long ${ }_{i}$ Hines \& Haddon unpubl.).

Third, postmolt crabs may gain an advantage in acquiring minerals or other nutrients by aggregating to molt. Although crabs are not actively feeding during the period around ecdysis, early postmolt crabs in the laboratory frequently consume their exuvia (pers. obs.), presumably in order to provide the minerals for recalcification of the exoskeleton (Vigh \& Dendinger 1982). If crabs in the field are frequently separated from their exuvia before feeding, molting aggregations would make it easy to find another individual's exuvium nearby.

Because copulation in blue crabs only occurs between intermolt males and females undergoing the pubertal molt, it is reasonable for prepubertal females to molt in the open-water basin where mature inter- 
molt males are abundant. However, it is not clear why juvenile females would not gain the same advantages as males by molting in the creek.

Our data on use of the tidal creek by molting male blue crabs provide one of the best documented cases of habitat partitioning for molting in a crustacean. Additional experimental analysis will be necessary to evaluate the adaptive significance of this partitioning. However, these data indicate that habitat utilization within estuaries by blue crabs is considerably more complex than that indicated by the life history paradigm of Callinectes sapidus (Van Engle 1958, Millikin \& Williams 1984).

Acknowledgements. We thank Lynn Wiechert, Sharon Hosko, Patty Haddon, Merle Potchinsky, Mark Tedesco, Craig Kelly, Jim Schafer, Jim Duls, and Kathy Paige for many hours of field assistance. Austin Williams, Jim Stretch, and Erik Scully made helpful suggestions on earlier drafts of the manuscript. This research was supported in part by National Science Foundation Grant No. BSR-8316948, the Smithsonian Environmental Sciences Program, the Smithsonian Postdoctoral Fellowship Program, the Smithsonian Scholarly Studies Program, the Work/Learn Internship Program of the Smithsonian Environmental Research Center, and the Maryland Department of Natural Resources.

\section{LITERATURE CITED}

Aiken, D. E. (1973). Proecdysis, setal development, and molt predicition in the American lobster (Homarus americanus). J. Fish. Res. Bd Can. 30: 1337-1344

Arnold, W. S. (1984). The effects of nrey size, predator sizc, and sediment composition on the rate of predation of the blue crab Callinectes sapidus Rathbun on the hard clam, Mercenaria mercenaria (Linné). J. exp. mar. Biol. Ecol. 80: $207-219$

Bliss, C. I. (1970). Statistics in biology, Vol. II. McGraw-Hill Book Comp., New York

Blundon, J. A., Kennedy, V. S. (1982a). Mechanical and behavioral aspects of blue crab, Callinectes sapidus (Rathbun), predation on Chesapeake Bay bivalves. J. exp. mar. Biol. Ecol. 65: 47-65

Blundon, J. A., Kennedy, V. S. (1982b). Refuges for infaunal bivalves from blue crab. Callinectes sapidus (Rathbun), predation in Chesapeake Bay. J. exp. mar. Biol. Ecol. 65: $67-81$

Born, J. W. (1970). Changes in blood volume and permeability associated with molting in a marine crab, Pugettia producta. Ph.D. thesis, University of California, Berkely

Botsford, L. W., Wickham, D. E. (1978). Behavior of agespecific density-dependent models and the northern California dungeness crab (Cancer magister) fishery. J. Fish. Res. Bd Can. 35: 833-843

Cargo, D. G. (1958). The migration of adult blue crabs, Callinectes sapidus Rathbun, in Chincoteague Bay and adjacent waters. J. mar. Res. 16: 180-191

Cooper, R., Uzmann, J. (1980). Ecology of juvenile and adult Homarus. In: Cobb, S., Phillips, B. (ed.) The biology and management of lobsters, Vol. II. Academic Piess, New York, p. 97-142

Drach, P. (1939). Mue et cycle d'intermue chez les crustaces decapodes. Annls Inst. océanogr., Monaco 19: 103-391
Epifanio, C. E., Valenti, C. C., Pembroke, A. E. (1984). Dispersal and recruitment of blue crab larvae in Delaware Bay, USA. Estuar. coast. Shelf Sci. 18: 1-12

Galtsoff, P. S. (1964). The American oyster, Crassostrea virginica Gmelin. Fish. Bull. U.S. 64: 1-480

Hartnoll, R. C. (1982). Growth. In: Abele, L. G. (ed.) The biology of Crustacea, Vol. 2, Embryology, morphology, and genetics. Academic Press, New York, p. 111-196

Heck, K. L., Jr., Orth, R. J. (1980). Seagrass habitats: The roles of habitat complexity, competition and predation in structuring associated fish and motile macroinvertebrate assemblages. In: Kennedy, V. S. (ed.) Estuarine perspectives. Academic Press, New York, p. 449-464

Heck, K. L., Jr., Thoman, T. A. (1984). The nursery role of seagrass meadows in the upper and lower reaches of the Chesapeake Bay. Estuaries 7: 70-92

Herrnkind, W. F. (1983). Movement patterns and orientation. In: Vernberg, F. J., Vernberg, W. B. (ed.) The biology of Crustacea, Vol. 7, Behavior and ecology. Academic Press, New York, p. 41-105

Hines, A. H., Haddon, P. J., Miklas, J. J., Wiechert, L. A., Haddon, A. M. (1986). Estuarine invertebrates and fish: Sampling design and constraints for long-term measurements of population dynamics. In: Boyle, T. (ed.) Longterm monitoring in aquatic ecosystems. Am. Soc. Test. Mater., Philadelphia, ASTM STP 940, p. 140-164

Holland, A. F. (1985). Long-term variation of macrobenthos in a mesohaline region of Chesapeake Bay. Estuaries 8: 93-113

Holland, A. F., Mountford, N. K., Hiegel, M. H., Kaumeyer, K. R., Mihursky, J. A. (1980). Influence of predation on infaunal abundance in upper Chesapeake Bay, USA. Mar. Biol. 57: 221-235

Homer, M., Mihursky, J. A., Jones, P. (1980). Quantitative approaches towards characterizing estuarine fish populations and communities. Proc. Am. Fish. Soc., Potomac Chaptei, 4 th Annual Meeting, p. 39-99

Hooper, R. G. (1986). A spring breeding migration of the snow crab (Chionoecetes opilio) into shallow water in Newfoundland. Crustaceana 50: 257-264

Krantz, G. E., Chamberlin, J. V. (1978). Blue crab predation on cultchless oyster spat. Proc. natn. Shellfish. Ass. $68: 38-41$

Laughlin, R. A. (1982). Feeding habits of the blue crab, Callinectes sapidus Rathbun, in the Apalachicola estuary, Florida. Bull. mar. Sci. 32: 807-822

Lipcius, R. N., Herrnkind, W. F. (1982). Molt cycle alterations in behavior, feeding and diet rhythms of a decapod crustacean, the spiny lobster Panulirus argus. Mar. Biol. 68: 241-252

Lipcius, R. N., Hines, A. H. (1986). Variable functional responses of a marine predator in dissimilar homogeneous microhabitats. Ecology 67: 1361-1371

Millikin, M. R., Williams, A. B. (1984). Synopsis of biological data on the blue crab, Callinectes sapidus Rathbun. FAO Fisheries Synopsis No. 138, NOAA Tech. Rept. NMF 51: 1-38

Norse, E. A. (1977). Aspects of the zoogeographic distribution of Callinectes (Brachyura: Portunidae). Bull. mar. Sci. 27 : $440-447$

Orth, R. J., Moore, K. A. (1983). Chesapeake Bay: An unprecedented decline in submerged aquatic vegetation. Science 222: 51-53

Peebles, J. B. (1977). A rapid technique for molt staging in live Macrobrachium rosenbergii. Aquaculture 12: $173-180$

Reaka, M. L. (1976). Lunar and tidal periodicity of molting and reproduction in stomatopod crustacea: a selfish herd 
hypothesis. Biol. Bull. mar, biol. Lab., Woods Hole 150: 468-490

Strathmann, R. R. (1982). Selection for retention or export of larvae in estuaries. In: Kennedy, V S. (ed.) Estuarine comparisons. Academic Press, New York, p. 521-536

Sulkin, S. D., Van Heukelem, W., Kelly, P., Van Heukelem, L. (1980). The behavioral basis of larval recruitment in the crab Callinectes sapidus Rathbun: a laboratory investigation of ontogenetic changes in geotaxis and barokinesis. Biol. Bull. mar. biol. Lab., Woods Hole 159: 402-417

Tagatz, M. E. (1968). Biology of the blue crab, Callinectes sapidus Rathbun, in the St. Johns River, Florida. Fish. Bull. U.S. $67: 17-33$

Tang, Q. (1985). Modification of the Ricker stock recruitment model to account for environmentally induced variation in recruitment with particular reference to the blue crab fishery in Chesapeake Bay. Fish. Res. 3: 13-21

Taylor, D. M., Hooper, R. G., Ennis, G. P. (1985). Biological aspects of the spring breeding migration of snow crabs, Chionoecetes opilio, in Bonne Bay, Newfoundland (Canada). Fish. Bull. U.S. 83: 707-711

Ulanowicz, R. E., Ali, M. L., Vivian, A., Heinie, D. R., Richkus, W. A., Summer, J. K. (1982). Identifying climatic factors influencing commerical fish and shellfish landings in Maryland. Fish. Bull. U.S. 80: 611-626

Van Engle, W. A. (1958). The blue crab and its fishery in the
Chesapeake Bay. Part I. Reproduction, early development, growth, and migration. Comml Fish. Rev. 20: 6-17

Van Herp, F., Bellon-Humbert, C. (1978). Setal development and molt prediction in the larvae and adults of the crayfish, Astacus leptodactylus (Nordmann, 1842). Aquaculture 14: 289-301

Vigh, D. A., Dendinger, J. E. (1982). Temporal relationships of postmolt deposition of calcium, magnesium, chitin and protein in the cuticle of the Atlantic blue crab, Callinectes sapidus Rathbun. Comp. Biochem. Physiol. 72A: 365-369

Vigh, D. A., Fingerman, M. (1985). Molt staging in the fiddler crab Uca pugilator. J. Crust. Biol. 5: 386-396

Virnstein, R. W. (1977). The importance of predation by crabs and fishes on benthic infauna in Chesapeake Bay. Ecology 58: 1199-1217

Virnstein, R. W. (1979). Predation on estuarine infauna: response patterns of component species. Estuaries 2: $69-86$

Williams, A. B. (1974). The swimming crabs of the genus Callinectes (Decapoda: Portunidae). Fish. Bull. U.S. 72 685-798

Wolcott, T G., Wolcott, D. L. (1985). Factors influencing the limits of migratory movements in terrestrial crustaceans. In: Migration: mechanisms and adaptive significance. Contr. Mar. Sci. (Univ. Texas) 27 (Suppl.): 257-273

This article was submitted to the editor; it was accepted for printing on December 2, 1986 